\title{
Social aspects of Code-Switching: An analysis of Pakistani Television advertisements
}

\author{
Aalia Mehar Khan \\ Fatima Jinnah Women University, Pakistan \\ aalia.khan05@gmail.com
}

\begin{abstract}
Code switching is the shift from one language to the other or use of more than one language during conversations or writings. The present research deals with intra-sentential (within one sentence) code switching in the language of television advertisements. To facilitate the socio-linguistic analysis, 12 advertisements of beauty and health care products have been recorded and transcribed from four television channels. The linguistic analysis focuses on the social aspect (gender, geographical background, socioeconomic class, and education) of code switched language in these advertisements. From the analysis and findings, it is concluded the language of advertisements for beauty and health care products reflects a change in linguistic practices and preferences of Pakistani consumers.
\end{abstract}

Keywords: Social aspects, code-switching, Pakistan, television

\section{Introduction}

In this age of technology, where information is on our fingertips, the need for communication is gaining a lot of importance. Human communication started with signals, signs, and sounds, went through the development of different languages and now reached the involvement of technology (radio, television, telephone, internet etc). The overnight changes in the modern world have changed the traditional notion of language as tool for communication. Language not only conveys messages but it has become ones' identity, an expression, and a source for socializing. Not only this technology, but language is also making the world compact, where we find multilingual societies. This phenomenon of multilingualism not only brings ease in communication, but considering the social aspect, it enriches different language and cloaks the speakers with variant identities. If we consider the issues of bilingualism, identity, and social schema in Pakistan, the history of our national language Urdu is significant. The influences of Persian and Arabic along with colonial impact (English culture), Urdu speakers have internalized such a language culture, where class based social setup continuously affects the language habits and practices. English being an international language is considered a language of prestige and people take pride in using English with their national language i.e. it associates them with the affluent. As we know that media speak the language of people and influence their language behaviours, in Pakistan, media present a social change where social strength and values are attached with rich people, who are sophisticated and speak modern language. This change is observable in advertising messages in general and advertisements of beauty products in particular (e.g. shampoos, hair colour, fairness creams), which set new standards of beauty for men and women. Beauty is also attached with social uplift, so these three concepts namely; language usage, social affluence, and beauty are seen co-existing in the language of advertisements. It is important to relate Pakistani linguistic scenario with advertisements in the light of changing trends and concepts of beauty.

Significance of the Research: The present research opens vistas for studying language practices in the discourse of advertisements for beauty products. The idea of clear skin and beautiful hair is gaining importance for men also and the introduction of men's specialized beauty products has changed the advertising messages. The language along with the setting and characters attracts the viewers in a different way and makes people aware of their beauty needs in the modern world.

\section{Literature Review}

Code-Switching: To Abudarham (1987:28) "Code switching is the alternate use of each language within the same utterance or conversation" and it can start only when DL (Dual Language) child is able to differentiate between two languages and their systems. Romaine (1995) treats code switching in the sense in which Bloom 
\& Gumperz (1982) have defined it i.e.' the juxtaposition within the same speech exchange of passages of speech belonging to two different grammatical systems or subsystems.' and according to Gardner- Chloros (1997:361), this is a common occurrence in many parts of the world e.g. Africa, India, Europe, United states in the form of bi- or multilingualism. Nilep (2006) defines code switching under socio-cultural linguistics as:

The practice of selecting or altering linguistic elements so as to contextualize talk in interaction. This contextualization may relate to local discourse practices, such as turn selection or various forms of bracketing, or it may make relevant information beyond the current exchange, including knowledge of society and diverse identities. (p.1)

This research will deal with the term code switching as the use of two languages (within one sentence) during conversation. Code switching is a very prominent feature of bilingualism and can occur between sentences i.e. inter-sentential or within a single sentence i.e. intra-sentential. Poplack (1980) (as cited by Romaine (1995)) has given three types of code switching i.e. tag switching, inter-sentential, and intra-sentential. This involves the insertion of a tag in one language into an utterance that is otherwise entirely in the other language. Romaine (1995) cites Poplack as well as gives explanation of inter- and intra- sentential code switching. Inter-sentential switching there is a language shift between sentences and each clause is in one language or another. For example: "kia ho raha hai? Ohh what happened?" or "Sometimes I'll start a sentence in English $y$ terminó in español"1. In intra-sentential switching, the speaker changes language within one sentence, e.g. "Capri say milay beautiful aur healthy skin sath sath."

Code Switching, Code Mixing, and Borrowing: Several scholars have attempted to define code switching and code mixing. As quoted by Ayemoni (2006:91), Hymes (1974) defines only code switching as "a common term for alternative use of two or more languages, varieties of a language or even speech styles." Ayemoni (2006) also cites Bokamba (1989) who has defined both concepts as:

Code-switching is the mixing of words, phrases and sentences from two distinct grammatical (sub) systems across sentence boundaries within the same speech event... code-mixing is the embedding of various linguistic units such as affixes (bound morphemes), words (unbound morphemes), phrases and clauses from a co-operative activity where the participants, in order to infer what is intended, must reconcile what they hear with what they understand. (p.91)

Linguists across the world have investigated in their experiments the causes, functions, characteristics and effects of code switching and code mixing. To differentiate between code switching and code mixing, Bing (1987:23) has explained code mixing as:

In code-mixed sentences, pieces of one language are used while a speaker is basically using another language. These 'pieces' of the other language are often words, but they can also be phrases or larger units. 'codemixing' is the shift of code found within one and the same clause or sentence.

Code switching in Pakistan: The study of code switching in Pakistan starts from the phenomena of bilingualism. Yousaf (2004) says that there is a constant language shift in Pakistan. A Pakistani child learns his mother tongue in home, becomes acquainted to Urdu, and as he grows older, he has to acquire the knowledge of English language for academic and official purposes. In present scenario, English is becoming a major part of our discourse. Whether it is a formal setting or an informal situation, English is being spoken along with Urdu. Niazi \& Khan (2003) takes a look at the practice of code switching by Teenage Bilinguals in Private schools and reports that English is taken as a mark of high status and success. It has taken a very important position in our society and youngsters (specifically) find it convenient to use both English and Urdu interchangeably. For them, it not only brings facility, but also adds to their social image.

Anwar (2007) presents an analysis of Urdu-English code switching in Pakistani English at the phrase and clause level. The examples have been extracted from Pakistani English newspapers and magazines

- We reached there in time, lakin no body was there to receive us. p.8

- An honorable sardar or wadera (the landlord or chief) can walk free even after proven record of the most heinous kinds of against crimes him. (March 27, 2007 Dawn) p.4

- He is called sher ka bacha (bashful, brave) and mard ka bacha (high minded). (January 08, 06 Dawn) p. 6

\footnotetext{
${ }^{1}$ Bilingualism and Code-Switching. Retrieved on April 23, 2008 from courses.essex.ac.uk/lg/lg232/blingcod.ppt
} 
- Mujhe shikayat hai (I have a complaint) that we are not making history. (July 31, 2005 Dawn) p.11

Code switching in Pakistani Media: For Talaat (2005), Code switching is not only a linguistic phenomenon but also a major social function of English in Pakistan and bringing a phenomenal linguistic change. This linguistic change is evident in both print and electronic media in Pakistan. We can see the reflection of linguistic practices of people in language of media. In newspapers code switching is in practice and few examples can be quoted from leading Urdu news daily:

- Awaam ko koi relief nahi mila.

- Supreme Court main judges ki tadaad barhanay kay liye act 33 tabdeel kia jaye.

- Pakistan main jamhooriat ka farogh hamari policy hai. (Jang, May 9, 2008)

From these examples, it is clear that English has become a part of our language, which is reflected by the language of our media and vice versa. This usage can be observed in the language of television as well.

Code switching in Pakistani television: Quaglio and Biber (2006) have cited Rey (2000:31) that popular media e.g. television is an appropriate source for the study of sociolinguistics and language trends, noting that: "while language used in television is obviously not the same as unscripted language, it does represent the language scriptwriters imagine that real women and men produce."In Pakistan, English being a second language and a language of academics is gaining great importance. The frequent usage of English language is evident in Pakistani television and this phenomenon is opening avenues for research in this area. Abbas (1998) is of the view that English language is frequently being used in Pakistani television especially in advertising. This practice is observable even in Urdu newspapers. Prof. Kaleem Raza ${ }^{2}$ has also studied code switching with relation to identity in Pakistani media i.e. Urdu newspapers and television programs in his research on identity and code switching with reference to media. Miraj (1993) has also worked on the use of English in Urdu Advertising in Pakistan. In trade and commerce, English is used with Urdu in a bilingual context. The local companies and small trade generally use Urdu while the multinational enterprises use English as medium of communication; but in advertising, the situation is bilingual and both Urdu and English are in use.

Advertisements and Television: To discuss advertisements and their language, it is important to look at the term 'media', which is significant in bringing change in life styles, behaviour, and language patterns of the whole world. Shedding light on language in media, Johnson and Ensslin (2007) have talked about the term 'media'. For them, this term covers classical communication means i.e. newspapers/magazines, radio, cinema, television, and other electronic/ digital ways of communication. This term also encompasses all the tools and techniques that are used by 'intelligent mammals' to carry out their significant activities. To deal this term with reference to present study, media is used as classical ways of communication in general and television in particular. In today's world of technology, where information is always needed, no one can deny the importance and usefulness of media in the lives of individuals. Media reflect society as a whole rather than its division. We can see the reflection of cultural and social practices of a particular nation in media and according to Shamsudin (2003), in developing countries like Pakistan; media's role has cultural as well as psychological effect on people. The language portrayed in media 'help in integrating people psychologically and in making them western. Taking our discussion to how television propagates linguistic scenario, we will focus on advertisements on this medium. Advertising can be traced back to the very beginning of history. Archaeologists working in the countries around Mediterranean Sea have dug up signs announcing various events and offers. The Romans painted walls to announce gladiator fights, and the Phoenicians painted pictures promoting their wares on large rocks along parade routes. (Kotler and Armstrong 2004:494). Modern advertising is very different from these efforts and according to Kotler and Armstrong (2004), US advertisers now run up an annual advertising bill of more than $\$ 231$ billion; worldwide advertisement spending has reached up to $\$ 550$.

Khan and Ali (2003) have highlighted the significance of advertising that it has become an integral part our lives and society. Advertisements are an essential part of radio/television programs and newspapers. We see advertisements on Billboards, buses, vans, magazines, and even matchboxes. Advertising acts as a dynamic

${ }^{2}$ Featured Sessions Retrieved on May 4, 2008 from www.aku.edu/News/Seminars/cel2007/sem05-fs.pdf 
and forceful tool in moulding our attitudes, behaviour, and language usage. Their survey on the impact of television advertisements on consumer behaviour and attitudes shows that persuasive language and creative designing of advertising messages successfully influence consumers' attitude and buying behaviour. Kotler (2003:498) has discussed the creation of advertising message with reference to television advertisements. He is of the view that to gain and hold attention, today's advertising message must be better planned, more imaginative, entertaining, and rewarding to consumers. Language selection is very important in this process because "today we have to entertain and not just sell directly and come off as boring or obnoxious, people are going to press the remote on you." He quotes an advertising executive: "When most TV viewers are armed with remote channels switchers, a commercial has to cut through the cluster and seize the viewers in one to three seconds, or they're gone." Thus, it is clear that selection of creative and catchy language is very important to attract viewers and if we talk about advertisements on television, advertisers need to focus on the visual information (setting, people) as well as background music to support language in the creation of an advertisement.

Code Switching in advertisements on Television: Consumer researchers have investigated the effect of mixing languages in advertisements. Luna and Peracchio (2005) have studied the use of 'Spanglish' in advertising and looked at several advertising slogans that use code switching. They found that different languages mean different things to their users. For example, many Hispanics in the U.S. are bilingual, so they could use either Spanish or English interchangeably. However, they perceive English as the language of power and dominance. Spanish can be associated with a feeling of inferiority and discrimination. The research underlines the fact that even advertisements that are written in two languages (in "Spanglish") can awake associations (inferiority and discrimination), and that the same slogan can result in different reactions depending on the language that draws the most attention. For marketers, Luna and Peracchio highlight the importance of language and consumers' attitudes toward the language used in advertising and how code switching helps in understanding this phenomenon. This is particularly relevant for advertisers targeting bilingual markets.

Bishop (2006) has examined that how using language code switching in advertising is perceived by bilingual (Spanish/English) consumers, particularly those of Mexican-American descent. Her focus is on the effectiveness of code switched advertising (in terms of message recall, perceptions of advertisers' cultural sensitivity and expectations concerning the reaction of a service provider) may be positively or negatively affected by the language context of the medium. Gupta (2007:7) has collected almost 900 advertisements from newspapers and magazines and found that most of the advertisements' slogans used code mixed language. For example:

Tata tea : 'Taste kaamyabi ka!'

Coca-Cola: 'Life ho to aisi!'

Pepsi: 'Yeh dil mange more'

Radio City 91 FM: 'Relax ho jao. City mein kho jao'

Radio Mirchi: Mirchi sunnewaale, always khush'

Nestle: 'Taste bhi health bhi'

Nature Fresh oil: 'Khao light, Jiyo life!'

Examples in this paper show that code mixing in English advertisements is the sign of creativity and imagination. Code-mixing and language shift is a marketing strategy that attracts youth in metropolitan cities by using the language they use i.e. a mixture of English and Hindi. The above mentioned studies show that code switching and code mixing are operative not only in general discourse but we can observe this language change in media i.e. television advertisements also. As we know that advertisements are meant to target potential customers to buy a certain product that is why advertisers use language of the people to persuade them. This is observable in Pakistani advertisements also and if we compare the advertisements of today with the advertisements of 1970s, we can see the difference in language usage and the extent of code switching.

Study of Code Switching in Pakistani Television: The use of English has become a mark of modernity in advertisement development. English is considered as fashionable and it enjoys prestige because of medium of education and development of media. Frequent use of English with Urdu is not only obvious in everyday life but is palpable in media also. If we look at Pakistani television commercials, Saeed \& Khan (2004) has 
observed in her research (on commercials of PTV) that English language in Urdu advertisements is employed to channel the purchasing decisions of customer into directions determined by advertisers. People pay more attention when the commercial is attractive and delightful. Their buying decisions are greatly affected by the design and presentation of advertisements. Along with colourful presentation, fascinating sound, and imaging, code switched language (which is considered to be in vogue and modern) also plays a key role in this regard.

Sociolinguists and language choice: Human languages, according to Saleemi (2003) 'Require a good deal of socio-cultural input to acquire a concrete shape', which means that the language we speak and the meaning we convey is inferred from society in which we live and the culture which we follow. To study the conversational code-switching, we need to look at socio-cultural perspective because not only the social identity of the addressor, the addressee, and the person mentioned, play a role in determining the linguistic choices but also other factors in social context are closely interrelated to it. (Dilshad, 2007: 5) These factors include gender, geographical background, socioeconomic class, and education. These aspects also play a vital role in the extent of code switching when we analyze language of advertisements with reference to the characters and setting portrayed in advertisements. For Talaat (2005), Code-mixing in speech is not only a linguistic phenomenon but also a major social function of English in Pakistan and it is bringing a phenomenal linguistic change. This change is evident in the advertising patterns and promotional programs, which not only depict changing social norms and practices, but also paint a picture of our cultural and sub-cultural systems.

Nilep (2006) advocates that code switching is a kind of linguistic activity, which is evident in the speech of bilinguals involved in a certain discourse. It depends upon the usage of alternate grammatical systems or sub systems. The linguistic choices / preferences have a close relationship with the culture and life style of the speakers. Therefore, to study this linguistic practice, it is important to look at the social practices and norms of the people. Linguistic codes emerge from social interaction, and become relevant when parties involved in discourse treat them as such. This research will also focus on the phenomenon of code switching with reference to the socioeconomic class and education of the speakers shown in the advertisements. Use of English in Urdu speech is socially considered as a sign of aristocracy and a portrayal of being highly educated so the context (nature of the product) and characters in the selected advertisements will help in determining the role of one's financial position and education in his/ her linguistic choices.

\section{Methodology}

For socio-linguistic analysis of advertisements, twelve television advertisements have been recorded and transcribed from four television channels including PTV, Geo News, AAJ TV, and TV-One. The collected data includes advertisements of soaps, shampoos, hair colour and fairness creams. The socio-linguistic analysis focuses on the use of code switched language in these advertisements; and the instances of code switching/ code mixing have been viewed considering that English has now achieved the status of lingua franca and in Pakistani linguistic scenario, high prestige is attached to this language. Social aspect of the present research answers such questions as how and why social setup, background setting, characters etc. (that are shown in advertisements) are related to the use of mixed language.

Interpretation and Analysis: As mentioned earlier, the data of the research comprises twelve television advertisements. These advertisements are of beauty and health care products (beauty/anti bacterial soaps and shampoos, hair colors and fairness creams etc). The language of this advertisement has been analysed from sociolinguistic perspective.

Section 1: Generally, beauty products address consumers by offering an ultimate solution to their problems. The language for these advertisements is selected carefully to evoke a desire in the viewer to look young and beautiful. With the changing discourse patterns of the people, the language of advertisements for beauty and health care products is undergoing a change. Code switching is observable in these advertisements and we find a mixture of Urdu and English in the language of these commercials. The components and ingredients of the beauty products are generally reported using foreign lexical items. Beauty products generally target young females as their buyers, so modern language and embellished setting is selected, which gives them a 
feeling of social uplift and a dream of better life full of beauty, youth, and elegance. As far as healthcare products are concerned, code mixed language is used to exploit people's knowledge about discourse relevant to health and cleanliness. We are more familiar with the usage of items like "germs", "antiseptic", and "virus and bacteria" as compared to Jaraseem and Jaraseem Kush in Urdu. The words like "virus" and "bacteria" have no substitutes in Urdu, but their excessive and contextual usage makes us understand that virus and bacteria are different. Viruses are much smaller and infectious. This information is important to be conveyed and only code mixed language can effectively communicate this message.

Soaps and shampoos are products of daily use and their advertisements promise a clean and healthy life. Marketers carefully select such language items, which not only promise to give beauty and health but also give an insight into the composition of the product. This suggests a change in message design because people are health conscious and this knowledge is at their hands in the form of television, radio, and newspapers. We find the use of items such as "doctors kee number one choice", "international formula", "Be hundred percent sure", and "beautiful aur healthy skin" in the commercials of beauty/ antibacterial soaps. It is interesting to note that in the phrase "international formula", "International" is called Bain-ul-aqwami in Urdu, while "formula" is known as Nuskhaa and "formula" as such. This phrase means that the product is manufactured according to international components and standards and the phrase bain-ul-aqwami nuskhaa is confusing and difficult as compared to "international formula". The phrase "number one choice" means Awaleen intekhaab/ pehla intekhaab in Urdu and it is used in both the languages depending upon the linguistic choice of speakers, but nowadays the use of English equivalent is in vogue and it suggests strong social image. The advertisements of shampoos promise long, healthy, and shiny hair by using such a language, which would attract young and fashionable viewers, especially girls and young women. The phrases "shinning princess", "milk treatment", "do guna soft", "do guna strong" (do guna means "two times"), and "shinning personalities" ("shinning" means Chamkeeli) substantiate this point well. The word "shine" means chamak in Urdu and the advertisements targeting young females communicate that the usage of so and so shampoo would not only bring shine in their hair but their personality also. For anti-dandruff shampoos, the choice of phrases such as "Clear Men", "no dandruff", and "germ guard formula" is indicative of the fact that people have now become health conscious.

It is evident from the collected data that beauty products for men have also been introduced and their brand names are coined in a way to attract male customers, for example, "Clear Men" and "Fair Menz Fairness Cream". With the changing lifestyle and media invasion, men are becoming conscious of their looks and health. This desire to look good and healthy has instigated a change in the concept of beauty i.e. men should also have fair and clear skin with shiny hair. As a result, demand for such specialized products for men has increased. The advertisements of hair colour and fairness creams are designed as providing a perfect solution to the problems of hair and skin. The commercials of hair colors promise full grey coverage and zero damage, while fairness creams open a new world of beauty, where a buyer will certainly get fair, glowing, and spotless face. For example, "beauty parlour jaisa nikhaar" and "chehra ek dam cool, fair, and dashing". "Beauty Parlour" is an English compound in the hybridized noun phrase "beauty parlour jaisa nikhaar", while the use of "cool, fair, and dashing" conveys a linguistic change in the language patterns of our youth. The words "cool" and "dashing" have no linguistic and contextual equivalents in Urdu and these are frequently seen in the discourse patterns of youngsters who aspire to become modern. The modern attire and fashionable looks of characters in such advertisements also substantiate this point very well. The language used for such advertisements is not only promising but it also enlists all the attributes (chemical composition and improved formulae) that a product carries. For example, "international pack", "advanced stabilized developer", and "Naye style ka brush applicator". "Naye style" in this phrase can be used as naya andaz in Urdu or "new style" in English. . These phrases describe the characteristics of the product and there are no chaste Urdu terminologies for these phrases (especially for "advanced stabilized developer"). It is notable that a complete English phrase can be mixed but there is a possibility of creating a variant of phrases by hybridizing a phrase i.e. some part of phrase is in Urdu and some in English language.

The names of such products are also interesting to note, for example "Kala Kola" means the one which gives black hair, "Fair \& Lovely Multi Vitamin Fairness Cream" (note the use of "fair and lovely" and "multi vitamin") , "Saafi" (which clears all blemishes), and "Fair Menz fairness cream". "Fair Menz" means that the cream is manufactured for male skin and it gives fair complexion. This brand name is attractive, modern 
(usage of "Menz" instead of Men's), and apt to use like "Clear Men" (a shampoo for men). To discuss social aspect of these advertisements, it is important to note that fair complexion, rosy cheeks, clear skin, and long shiny hair are an emblem of real beauty in our society. To strengthen this idea, the characters in such advertisements are high profiled, (a celebrity is shown in the advertisement of hair colour, a worker in a beauty parlour becomes a model after using the fairness cream, and young rich girls are shopping in a big mall for the commercial of beauty soap etc). The setting is embellished (the model is giving a shot in a decorated studio and the households in these advertisements are well to do) and the language is modern, which convey the message that the usage of such products would bring a change in a customer's life and ultimately in his/her social status. It is interesting that those products which are used by lower and lower middle class also present magnificent and stylish images with modern language in the advertisements. These strategies are employed to create a desire of socio-economic strength and affluence in the viewers, so that they can also associate themselves with the people of upper class.

\section{Conclusion}

The collected data and analysis of the sections reveals that Urdu is undergoing the process of enrichment through code switching and mixing, but we can also find some instances of structure/ word exploitation for the purpose of modernity and affluence. As a result, a new variety of Urdu is emerging where we see a change in structures, phonology, and usage. Language of the data shows that people tend to code switch and code mix not only because of aptness and fluency but this practice also indicates their affinity for the language of prestige i.e. English, which is considered an emblem of socio-economic strength, and sophistication. With reference to language of advertisements in Pakistan, it is observed that advertising messages are being skillfully designed, with the high profile of participants and embellished setting to convey that a particular product not only brings beauty but social affluence as well. As we know that in our culture, the concept of beauty for men and women is changing day by day (i.e. materialistic and class based) and it is directly linked with the use of modern and mixed language. The language of these advertisements clearly depicts desires of common people to be a part of upper class by following new trends of beauty. This linguistic practice on part of bilinguals is giving birth to a new language culture, which makes us aware that a language should be enriched with inclusion of foreign language structures, but still maintaining its monolingual identity.

\section{References}

Abbas, S. (1998). Socio-political Dimensions in Language: English in Context in Pakistan. Journal of Applied Language Studies, 2, 23-41: Department of Education, New Post Graduate Block, Kinnaird College for Women, Lahore.

Abudarham, S. (1987). Bilingualism and the Bilingual. Berkshire: The NFER-NELSON Publishing Company Ltd.

Anwar, B. (2007). Urdu English code switching: The use of Urdu phrase and clauses in Pakistani English (A Non-Native Variety). ESP World, 17, 1-14.

Ayemoni, M. O. (2006). Code-Switching and Code-Mixing: Style of Language Use in Childhood in Yoruba Speech Community. Nordic Journal of African Studies, 15(1), 90-990

Bing, L. Y. (1987). Constraints on intrasentential code-mixing in Cantonese and English. (Research paper, University of Hong Kong).Retrieved on February 24, 2008 from sunzi1.lib.hku.hk/hkjo/view/45/4500102.pdf

Bishop, M. M. (2006). The role of Language Code switching in increasing advertising effectiveness among Mexican-American Youth. (PhD. Thesis, The University of Texas at Arlington, 2006). Retrieved on March 6, 2008 from dspace.uta.edu/bitstream/10106/13/1/umi-uta-1510.pdf

Dilshad, S. (2007). Verb Hybridization: An interesting aspect of the spread of English in Pakistan. Journal of Research: Faculty of Language \& Islamic Studies, 11, 37-51: Bahauddin Zakariya University Multan.

Gardner-Chloros, P. (1997). Code switching: Language Selection in Three Strasbourg Department Store. In Coupland, N. \& Jaworski, A. (Eds.). Sociolinguistics A Reader and Coursebook. Mcmillan Distribution Ltd.

Gupta, R. (2007). Bilingual Advertising in a Multilingual Country. Language in India, 7(4). April 2007. Retrieved April 10, 2008 from www.languageinindia.com/april2007/bilingualadvertising.pdf

Hymes, D. H. (1974). Foundations in sociolinguistics: an ethnographic approach. Philadelphia: University of Pennsylvania Press. 
Johnson, S. \& Ensslin, A. (2007). Language in the media: Theory and Practice. In Johnson, S. \& Ensslin, A. (Ed.). Language in the Media. London: Continuum International Publishing Group.

Khan, A. \& Ali, S. (2003). Effect of Advertising on Consumer Psychology. Journal of Social Sciences \& Humanities, 1(1), 116-127. Islamia University Bahawalpur.

Kotler, P. \& Armstrong, G. (2004). Advertising, Sales Promotion, and Public Relations. Principles of Marketing. (10 Ed.). (pp. 493-524). Singapore: Pearson Education.

Kotler, P. (2003). Marketing Management. New Delhi: Prentice-Hall.

Luna, D. \& Peracchio, L. A. (2005). Advertising to Bilingual Consumers: The Impact of Code-Switching and Language Schemas on Persuasion. Retrieved Feb 28, 2008 from http://www. acrwebsite.org/topic.asp?artid=225

Miraj, S. (1993). The Use of English in Urdu Advertising in Pakistan. In Baumgardner (Ed.). The English Language in Pakistan. Karachi: Oxford University Press.

Niazi, A. \& Khan, S. L. (2003). A Study of Language Attitudes and Motivations: English- Urdu Code switching by Teenage Bilinguals in a Private School. FJWU Abstracts: English. Fatima Jinnah Women University Rawalpindi.

Nilep, C. (2006). Code switching in Socio-cultural linguistics. Colorado Research in Linguistics, 19(3). Boulder: University of Colorado. Retrieved on April 23, 2008 from www.colorado.edu/ling/CRIL/Volume19_Issue1/paper_NILEP.pdf

Quaglio, P. \& Biber, D. (2006). The Grammar of Conversation. In Aarts, B. \& McMahon, A. (Ed.). The Handbook of English Linguistics. Oxford. Blackwell Publishers.

Romaine, S. (1995). Code switching and Communicative Competence. In Bilngualism. (pp.120-180). Oxford: Blackwell Publishers.

Saeed, M. \& Khan, S. L. (2004). Use of English language in PTV Urdu Commercials. FJWU Abstracts: English. Fatima Jinnah Women University Rawalpindi.

Saleemi, A. P. (2003). Mental and social aspects of Linguistic reality: The mind's language and its social reality. In Joan L.G Baart \& Ghulam Hyder Sindhi (Eds.), Pakistani Languages and Societies: Problems and Prospects. (pp.115-120). National Institute of Pakistani Studies, Quaid-e-Azam University and Summer Institute of Linguistics United Kingdom.

Shamsudin, M. (2003). Media in developing Countries. Journal of Social Sciences \& Humanities, 1(1), 5-12. Islamia University Bahawalpur.

Talaat, M. (2005). Convergence and Social Context in Pakistani English. ELF Annual Research Journal, 4, 27-48: Shah Abdul Latif University Khairpur.

Yousaf, F. (2004). Sociolinguistics: Study of Language in the Social Context. Journal of Research: Faculty of Language \& Islamic Studies, 6, 17-25: Bahauddin Zakariya University Multan.

\section{APPENDIX}

\section{Advertisement-1 January 3, 2008 (TV-1)}

1. Sardiyon main nazla zukaam kee beemaree bohat aam ho jatee hai aur hamaray apnay hee haathon kay zareye poori family ko apni lapait main lay leti hai

2. Nazla zukaam kay jaraseem say ghar bhar ki hifazat kay liye doctors kee number one choice hai Safeguard!

3. Abb paish hai Safeguard jo madad karay nazla zukaam kay jaraseem ko khatam karnay main.

4. Nazla zukaam say hifazat aap kay apnay haath main hai! Nazla zukaam say hifazat kay liye, doctors kee number one choice, Safeguard.

Advertisement-2 February 11, 2008 (PTV)

1. Khelnay deti hoon. Mazay karnay deti hoon. Kiyoon kay woh jo aa gaya hai. Nayaa Dettol soap. Kya kaha? Iss main nayaa kya hai? Nayaa hai iss ka international formula, Dettol kee taaqat kay saath. Jo tarah vtarah kay jaraseem yaani virus aur bacteria kaa yaqeeni khaatma. Tabhee tu hum roz istemaal kartay hain.

2. Aur bataaon nayaa kya hai?? Iss ka moisturizer say bharpoor jhaag jo jild ko rakhay sehat mand, narm aur mulaaim. Nayee hai iss ki khushboo jo rakhay mehktaa. Naye hain iss kay paanch mukhtalifandaaz. 
3. Nayaa hai meri family kaa harr din. Naye Dettol soap kay saath. Abb main poochon! Rozaana istemaal kay liye hai koi Dettol soap say barh kar?

4. Dettol soap. Be hundred percent sure harr roz.

Advertisement-3 February 11, 2008 (TV-1)

Kya aap banna chaahti hain Pakistan kee pehli shinning princess? Tu hamain bataain apni dream wish aur baahar laain apnay andar chupee shinning princess. Naye ferozi Pantene kay saath, 'Shine princess- shine Pantene'. Two Thousand Eight main bann jaain 'Pantene Shine Princess'. Apply karnay kay liye dekhiye magazines.

Advertisement-4February 11, 2008 (PTV)

1. Jesay kisee international salon main meray baalon ko milk treatment day raha ho bilkul issi tarha Pantene karta hai meray baalon ki nash-o-numaa.

2. Pehlee baar forty percent milky lotion aur conditioner kay saath milky Pantene baalon main jazb ho kar inhain banaain do guna soft, do guna strong. Sirf do haftay main.

3. Aap kay baalon kay liye doodh say behtar aur kya?

4. Milky Pantene! Forty percent milky lotion kay saath. Shine Pantene.

Advertisement-5 February 11, 2008 (TV-1)

Eight finalists_eight shinning stories_aur eight shinning personalities. Kaun banay gee Pantene Shine Princess? Kaun karay gee sabb ko outshine. Vote day kar faisla aap karain, kiyoon kay ek hi ho saktee hai Pantene Shine Princess.

Advertisement-6 March 8, 2008 (Aaj TV)

1. Hamaari wish list ek tu khatam nahi hotee

2. Aur compromise karna hamain aata nahee.

3. Tabhee tu hamain koee koee samajhta hai.

4. Jesay Capri!

5. Jiss say milay beautiful aur healthy skin saath saath.

6. No Compromise!

7. Capri kee natural skin care range

8. Capri Simply the Best!

Advertisement-7 March 8, 2008 (TV-1)

1. Egham Research centre England main hamain maloom hai mardon aur aurton kee sarr kee jild main kya farq hai. Mardon kee sarr kee jild zyada oily hai, iss liye dandruff kaa khatra bhee zyada hai aur baal girnay ka bhi.

2. Yehee waja hai kay hum nay tayyaar kia hai nayaa 'Clear Men'. Mardon kay liye anti-dandruff shampoo kee pehli specialized range. Naaya 'Clear Men'. No dandruff.

Advertisement-8 March 9, 2008 (PTV)

1. Uff__Kya hai ye? Aur ye?

2. Hair brush

3. Dandruff! Tumhaari dandruff. Harr taraf_ Aaah Mera takiyaa_Ammi_ Ye meri party main nahee aaye ga. Please!

4. Betaa! Bhaai hai tumhaara.

5. Bhai nahee factory hai dandruff kee.

6. Yeh laraai chor dijeeay Lifebuoy kay naye anti-dandruff shampoo pay. Iss kaa germ guard formula,dandruff kaa sau feesad khaatma karay.

7. Happy Birthday!

8. Kaun hai yeh?

9. Meraa bhaai!!

10. Nayaa Lifebuoy anti-dandruff shampoo.

Advertisement-9 January 29, 2008 (PTV)

1. Yehi tu hai sab kuch. 
2. Jee haan Kala Kola ab naye international pack main

3. Advanced stabilized developer matlab colour esay hi naa jaye jamm jaye. Naye style ka brush applicator. Different hai naa! Twenty percent extra cream Kiyoon kay sab kuch tu hai iss main!

4. Kala Kola smart bachat kay sath aur kya chahiye. Sab kuch tu hai iss main!

Advertisement-10 February 4, 2008 (Aaj TV)

1. Ho gaya?

2. Haan ho gaya

3. Thank You

4. Aray meri client!!

5. Kitnon ko mash-hoor bana chuki ho, tum kab mash-hoor bano gi?

6. Rozaana beauty parlour jaana paray ga customer bann kay.

7. Naee Fair \& Lovely Multi Vitamin Fairness Cream. Iss kay chaar vitamin dain chaar parlour treatment ka asar. Chaar hafton main beauty parlour jaisa nikhaar. Naee Fair \& Lovely Multi Vitamin Fairness Cream.

Advertisement-11 April 4, 2008 (Aaj TV)

1. Tobbah hai shaadi main chand hi haftay reh gaye hain aur kaam hai kay khatam hee nahee ho rahaa hai.

2. Ye daagh tu chupp jaain gay magar inhain bhee tu chupaao.

3. Kaisay chupaaon?

4. Tumhain inn ka mukammal ilaaj karna ho gaa. Yaad hai college main saima ko bhee yehee problem thee.

5. Phir?

6. Phir uss nay kiya Saafi kaa practical. Ye lo yehee hai natural solution.

7. Saafi, jiss kay qurati ajzaa khoon main shaamil ho kar karain keel muhaasson aur daagh dabbon ka andar say khaatma karain aur aap rahainn shadaab.

8. Aur practical kamyaab hooa. Abb inn per bhee...

9. Kya?

10. Haan practical kar kay dekho.

Advertisement-12 April 4, 2008 (Geo News)

1. Fair Menz fairness cream?

2. Yoon set ho gee_Life!!

3. Teen din kay andar andar apna rang dekhna.

4. Ye rang goraa kartee hai?

5. Haan. Dhoop kee rang jalaanay waali shuaaon say bhee bachaati hai. You know! Bike wike. Aur ye chotee motee jhurriyaan aur shaving kay cuts wuts. Matlab chehra ek dam cool, fair, and dashing.

6. Yoon set hogee_Life!

\section{Transcription Key}

1. Words from Urdu language have been italicized, while English words are not.

2. The names of the products and companies are not italicized.

3. For transcription of Urdu advertisements with conversation, '.' indicates pause and '...' is used where the speaker is interrupted or he/ she deliberately drops/ leaves the conversation.

4. For the transcription of advertisements, the utterance of new speaker or narrator in the advertisement is numbered. For example:

1) Yehi tu hai sab kuch. (participant in advertisement)

2) Jee haan Kala Kola ab naye international pack main. (Narrator)

5. The pronunciation rules for certain symbols in transcription of Urdu words are given below:

a) 'aa' symbol indicates long /a:/ sound as in the word 'class'. For example, Urdu baal and beemaar contain long /a:/ sound.

b) The symbol 'a' is used for the vowel sound $/ \wedge /$ as in the word 'run' and 'butter'. For example, Urdu words Foran and Zaroorat have the sound $/ \wedge /$ and the symbol ' $a$ ' is used for their transcription. 
c) For the long /i:/ sound, the symbol 'ee' is used as in the word 'seat' and 'sweet'. Urdu words Qeemat and Jaraseem have /i:/ sound. On the other side the word Kisee has short /i/ sound at first place and long /i:/ sound in the second place.

d) The symbol 'oo' is used for the long vowel sound / $u$ :/ as in the word 'fool' and 'school'. Urdu word Zaroorat and Kiyoon have /u:/ sound. For the Urdu words having short /u/ sound for example, Kuch, the symbol 'u' is used as in the words 'put' and 'bush'.

e) Urdu language has two types of /k/ sound. ' $\mathbf{k}$ ' symbol is used for the Urdu word like Kaam and ' $\mathbf{q}$ ' symbol indicates the words like Qareeb and Qeemat.

f) For the words with / $\mathrm{t} \int /$ sound, 'ch' symbol is used for example the word Chaar and 'sh' indicates $/ \int /$ sound as in the word Shaam.

g) The symbol 'ph' is used for aspirated /p/ sound / $\mathrm{Ph} /$ as in the word 'pot'. Urdu word Phir has $/ \mathrm{Ph}^{\mathrm{h}}$ / sound. 